Volume 2 Nomor 2, Desember 2019 E-ISSN : 2655-7347

\title{
ANALISIS KEKUATAN HUKUM PERJANJIAN LISAN ARISAN ONLINE YANG MENGGUNAKAN MEDIA APLIKASI FACEBOOK MESSENGER DALAM PEMBUKTIAN DI PENGADILAN DITINJAU DARI UNDANG- UNDANG INFORMASI DAN TEKNOLOGI ELEKTRONIK NOMOR 11 TAHUN 2008 (STUDI KASUS PUTUSAN NO. 106/PDT.G/2017/PN.PLK)
}

\author{
Lidya Puspita \\ (Mahasiswa Program S1 Fakultas Hukum Universitas Tarumanagara) \\ (E-mail : lidyapuspita126@gmail.com)
}

\author{
Dr. Ariawan Gunadi, S.H., M.H \\ (Corresponding Author) \\ (Dosen Fakultas Hukum Universitas Tarumanagara, Meraih Sarjana Hukum pada Fakultas Hukum \\ Universitas Tarumanagara, Magister Hukum pada Fakultas Hukum Universitas Indonesia) \\ (E-mail : ariawangun@gmail.com)
}

\begin{abstract}
Oral Agreement in verdict number 106 / pdt.g / 2017 / pn.plk explain concerning the matter between Ahinny as a plaintiff and Lucia as one of a defendant. These problems starts with mutual agreement do online social gathering that contained in facebook messenger, When the defendant won the online social gathering, the defendant as participant of that would no longer make the online social gathering contributions they were due to pay. The methodology of the research is normative method. The problem arises in this research is how the legal force of oral online social gathering that using media application facebook messenger in proof in court in terms of the law of information and technology electronic number 11 years 2008. The online arisan oral agreement in this case is an oral agreement with mutual trust between one another and will give rise to rights and obligations among the participants. This agreement will have legal force if the parties have agreed to hold an arisan with a value of money or certain goods and within a certain period of time, then actually an agreement has occurred among the participants of the social gathering. Facebook is intermediary and Facebook is not a responsible for disputes or defaults that occur between the online arisan parties. Based on technological advances and the rapid development of information techniques, the Government should immediately recognize that electronic evidence must be recognized and used as evidence in court.
\end{abstract}

Keywords : The Online Social Gathering, Oral agreement 
Lidya Puspita \& Ariawan Gunadi ANALISIS KEKUATAN HUKUM PERJANJIAN LISAN ARISAN ONLINE YANG MENGGUNAKAN MEDIA APLIKASI FACEBOOK MESSENGER DALAM PEMBUKTIAN DI PENGADILAN DITINJAU DARI UNDANG- UNDANG INFORMASI DAN TEKNOLOGI ELEKTRONIK NOMOR 11 TAHUN 2008 (STUDI KASUS PUTUSAN NO. 106/PDT.G/2017/PN.PLK)

Volume 2 Nomor 2, Desember 2019

E-ISSN : 2655-7347

\section{PENDAHULUAN}

\section{A. Latar Belakang}

Pada era saat ini, di mana perkembangan internet berkembang pesat seiring perkembangan zaman dan kehadirannya mampu menawarkan berbagai kemudahan dalam hidup, berbisnis, pertemanan dan lain-lain yang berbentuk virtual. ${ }^{1)}$ Ada banyak hal yang bisa dilakukan melalui penggunaan internet saat ini mulai media sosial, bekerja atau bahkan berbisnis secara online, tak terkecuali arisan secara online. Pada dasarnya, arisan adalah suatu bentuk pengumpulan uang atau bahkan barang yang memiliki nilai sama dari persepsi banyak orang, selanjutnya arisan tersebut diundi atau dikocok bersama dengan anggota arisan mereka. Proses undian tersebut dilakukan secara berkala sampai semua anggota memperoleh arisan. ${ }^{2)}$

Saat ini arisan menjamur tak terkecuali arisan online yang dilakukan secara mudah dan praktis. Transaksi pembayaran uang arisan dapat dilakukan melalui Anjungan Tunai Mandiri. Pelaksanaan undian aarisan dilakukan menggunakan sarana media elektronik, sehingga dalam hal ini diperlukan kepercayaan dalam melakukan bisnis ini. Arisan online sebagai bentuk perkembangan teknologi/internet saat ini. Dalam hubungan ini, arisan online pada dasarnya membutuhkan suatu perjanjian. Surat perjanjian arisan online dibuat dan disepakati bersama oleh kedua belah pihak. Ini artinya bahwa suatu perjanjian arisan pada dasarnya akan menimbulkan suatu hak dan kewajiban di antara para peserta arisan, meskipun dalam perjanjian arisan online rentan terjadi penipuan dan lain sebagainya.

Pada dasarnya perjanjian dalam konsep arisan tersebut diatur secara berbeda dalam KUH Perdata. Dalam hal ini, Buku III Bab II tentang Perikatan-perikatan terdapat suatu aturan atau ketentuan kontrak atau

\footnotetext{
1 1) Agus Rahardjo, Cyber Crime Pemahaman dan Upaya Pencegahan Kejahatan Berteknologi, (Bandung: Citra Aditya Bakti, 2002), hal. 20.

$2 \quad{ }^{2)}$ W.J.S. Poerwadarminta, Kamus Umum Bahasa Indonesia, (Jakarta: Balai Pustaka, 2007), hal. 59 .
} 
Lidya Puspita \& Ariawan Gunadi ANALISIS KEKUATAN HUKUM PERJANJIAN LISAN ARISAN ONLINE YANG MENGGUNAKAN MEDIA APLIKASI FACEBOOK MESSENGER DALAM PEMBUKTIAN DI PENGADILAN DITINJAU DARI UNDANG- UNDANG INFORMASI DAN TEKNOLOGI ELEKTRONIK NOMOR 11 TAHUN 2008 (STUDI KASUS PUTUSAN NO. 106/PDT.G/2017/PN.PLK)

Volume 2 Nomor 2, Desember 2019

E-ISSN : 2655-7347

perjanjian dan Bab V sampai dengan Bab XVIII di dalamnya juga diatur mengenai asas hukum dan norma hukum tentang perikatan / perjanjian yang memiliki karakteristik khusus yang lebih dikenal dengan perjanjian bernama. ${ }^{3)}$

Prestasi dalam perjanjian ialah suatu pelaksanaan terhadap hal-hal yang telah diperjanjikan atau yang telah ditulis di dalamnyua atas suatu perjanjian oleh kedua belah pihak guna mengikatkan diri untuk itu. Perbedaan atau lawan kata dari prestasi ialah ingkar janji atau istilahny wanprestasi yaitu tidak dilaksanakannya prestasi atau manakala janjijanji atau kewajiban tersebut sebagaimana yang dibebankan oleh perjanjian terhadap pihak-pihak tertentu dalam perjanjian dan juga sebagai bentuk pembelokan pelaksanaan perjanjian sehingga hal tersebut akan menimbulkan kerugian kepada pihak lain. ${ }^{4)}$ Berdasrkan hal tersebut, suatu perjanjian ini akan menerbitkan suatu perkataan antara dua orang yang membuatnya, dan bentuk perjanjian tersebut merupakan suatu rangkaian perkataan yang mengandung suatu janji atau kesanggupan yang diucapkan atau ditulis guna mengikat suatu perjanjian arisan. ${ }^{5)}$

Dalam penulisan karya ilmiah ini, penulis mengangkat kasus mengenai perjanjian lisan arisan online. Kasus ini terjadi antara Ahhiny, S. Hut., selaku Penggugat dan Lucia Setianae Subli selaku Tergugat I, Suciarni selaku Tergugat II, Jayanti Harta Leloni selaku Tergugat III, Titis Eka Wati selaku Tergugat IV, Novriani selaku Tergugat V, Yen Nie selaku Tergugat VI, Kacalinde selaku Tergugat VII, Mensy Fredelia Mihing selaku Tergugat VIII, Dewi Lastari selaku Tergugat IX dan Dwi Yaniarti selaku Tergugat X.

Penggugat dengan Para Tergugat, mengadakan kesepakatan bersama melakukan arisan online. Di mana kesepakatan bersama arisan online

\footnotetext{
$3 \quad{ }^{3}$ Muhammad Saifuddin, Hukum Kontrak: Memahami Kontrak dalam Perspektif Filsafat, Teori, Dogmatik dan Praktik Hukum, (Bandung: CV. Mandar Maju, 2012), hal. 32-33.

$4{ }^{4)}$ Munir Fuady, Hukum Kontrak (Dari Sudut Pandang Hukum Bisnis), Buku Kedua, (Bandung: PT. Citra Aditya Bakti, 2001), hal. 87.

${ }^{5)}$ R. Subekti, Hukum Perjanjian, (Jakarta: Intermassa, 1996), hal. 1.
} 
Lidya Puspita \& Ariawan Gunadi

ANALISIS KEKUATAN HUKUM PERJANJIAN LISAN ARISAN ONLINE

YANG MENGGUNAKAN MEDIA APLIKASI FACEBOOK MESSENGER DALAM PEMBUKTIAN DI PENGADILAN DITINJAU DARI UNDANG- UNDANG INFORMASI DAN TEKNOLOGI ELEKTRONIK NOMOR 11 TAHUN 2008 (STUDI KASUS PUTUSAN NO. 106/PDT.G/2017/PN.PLK)

Volume 2 Nomor 2, Desember 2019

E-ISSN : 2655-7347

bersifat perjanjian lisan dengan saling percaya antar satu sama lain. Arisan online yang dilakukan oleh pihak terkait dengan menggunakan media aplikasi facebook messenger.

Perlu diketahui bahwa arisan online tersebut dilakukan berdasarkan perjanjian atau kesepakatan bersama antar anggota dengan rasa saling percaya sebagaimana lazimnya arisan, hanya yang membedakan arisan yang diikuti oleh Penggugat dengan Para Tergugat dilakukan melalui aplikasi online atau melalui jaringan internet. Seiring waktu, arisan berjalan dalam kelompok (group) arisan yang dikelola oleh Penggugat sebagai admin berjalan dengan lancar sebagaimana arisan pada umumnya. Setelah lama berjalan, para Tergugat sudah mendapatkan giliran/kena arisan/menang arisan. Akan tetapi setelah Para Tergugat kena arisan/menang arisan, Para Tergugat sebagai peserta arisan itu tidak lagi membayar iuran arisan yang seharusnya mereka bayar. Demi menjaga kelancaran arisan dan karena Penggugat percaya kepada Para Tergugat bahwa akan membayar kepada Penggugat sejumlah uang yang dipinjami tersebut, maka Penggugat menutupi iuran yang harus dibayar oleh Para Tergugat. Seiring berjalannya waktu ternyata Para Tergugat tidak mengembalikan kepada Penggugat secara tunai melainkan secara cicilan, akhirnya terhambat dan sampai tidak lagi membayar kepada Penggugat, sehingga Penggugat yang harus menutupi pembayaran Para Tergugat yang kabur dan bahkan ingkar janji tidak membayar iuran arisan.

Besarnya iuran arisan yang tidak dibayar oleh Para Tergugat adalah bervariasi dengan jumlah keseluruhan adalah Rp.389.000.000,- dan Penggugat telah berusaha untuk menyelesaikan permasalahan ini secara musyawarah dan kekeluargaan akan tetapi Para Tergugat tidak memiliki iktikad baik untuk menyelesaikan permasalahan ini dan Para Tergugat menghilang begitu saja tanpa bisa dihubungi lagi. Penggugat telah mengirimkan satu persatu Somasi kepada Para Tergugat tertanggal 01 
Lidya Puspita \& Ariawan Gunadi

ANALISIS KEKUATAN HUKUM PERJANJIAN LISAN ARISAN ONLINE YANG MENGGUNAKAN MEDIA APLIKASI FACEBOOK MESSENGER DALAM PEMBUKTIAN DI PENGADILAN DITINJAU DARI UNDANG- UNDANG INFORMASI DAN TEKNOLOGI ELEKTRONIK NOMOR 11 TAHUN 2008 (STUDI KASUS PUTUSAN NO. 106/PDT.G/2017/PN.PLK)

Volume 2 Nomor 2, Desember 2019

E-ISSN : 2655-7347

Juli 2017 untuk membayarkan/mengembalikan dana yang sudah disetorkan Penggugat, namun balasan/tanggapan dari Para Tergugat sampai dengan gugatan ini, Penggugat mengajukan ke Pengadilan Negeri Palangka Raya. Para Tergugat tidak pernah membayar arisan lagi sehingga Penggugat harus menanggung semua iuran/pembayaran arisan.

Penggugat juga sudah tidak mampu lagi membayar arisan karena harus menutupi iuran arisan Para Tergugat, sehingga Penggugat menjadi sasaran dan dikejar-kejar oleh para peserta arisan lainnya karena juga tidak mampu membayar iuran arisan. Perbuatan Para Tergugat yang telah kena arisan atau sudah menang arisan akan tetapi tidak lagi membayar arisan sebagai kewajiban mereka merupakan perbuatan ingkar janji atau wanprestasi. Akibat perbuatan Para Tergugat yang tidak membayar lagi arisan, Penggugat menjadi dirugikan sebesar Rp.389.000.000,- Berkaitan dengan alat bukti lisan belum disebutkan dan dijelaskan secara spesifik di dalam pasal-pasal tersebut. Ini artinya bahwa bukti berupa saksi, seperti tertera dalam Pasal 1905 KUHPerdata. Ini artinya bahwa suatu perjanjian lisan harus mengacau pada asas hukum perjanjian diantaranya adalah pacta sun servanda, yaitu seperti dijelaskan dalam Pasal 1338 KUH Perdata.

Berdasarkan Undang-Undang Nomor 11 Tahun 2008 tentang Informasi dan Transaksi Elektronik (UU ITE) Pasal 5 ayat 2 menyatakan bahwa informasi elektronik dan/atau dokumen elektronik dan/atau hasil cetaknya sebagaimana dimaksud pada ayat (1) merupakan perluasan dari alat bukti yang sah sesuai dengan hukum acara yang berlaku di Indonesia. Dalam kasus ini digunakan facebook messenger sebagai wadah dalam melaksanakan perjanjian lisan arisan online.

Perjanjian lisan memiliki hubungan hukum yang sangat kompleks dan sulit dalam pembuktiannya, terutama terkait arisan online yang sedang marak terjadi. Namun di dalam Putusan Pengadilan Negeri Palangkaraya No. 106 / Pdt.G / 2017 / PN.PLK hakim memutuskan 
Lidya Puspita \& Ariawan Gunadi ANALISIS KEKUATAN HUKUM PERJANJIAN LISAN ARISAN ONLINE YANG MENGGUNAKAN MEDIA APLIKASI FACEBOOK MESSENGER DALAM PEMBUKTIAN DI PENGADILAN DITINJAU DARI UNDANG- UNDANG INFORMASI DAN TEKNOLOGI ELEKTRONIK NOMOR 11 TAHUN 2008 (STUDI KASUS PUTUSAN NO. 106/PDT.G/2017/PN.PLK)

Volume 2 Nomor 2, Desember 2019

E-ISSN : 2655-7347

Tergugat Bersalah dan didalam amar putusannya hakim menerima dan mengabulkan gugatan Penggugat untuk sebagian. Menjadi menarik jika dikaitkan dengan pembuktian elektronik (online) di dalam perkara perdata di pengadilan.

\section{B. Rumusan Masalah}

Mengacu pada uraian latar belakang masalah di atas, rmusan masalah yang dihadapi penulis yakni :

1. Bagaimana kekuatan hukum perjanjian lisan arisan online yang menggunakan media aplikasi facebook messenger dalam pembuktian di pengadilan ditinjau dari UU ITE (Studi pada kasus Putusan No. 106/Pdt.G/2017/PN.PLK)?

2. Bagaimana tanggung jawab facebook dalam hal perjanjian lisan arisan online yang menggunakan media aplikasi facebook messenger apabila terjadi wanprestasi?

\section{Metode Penelitian}

Pada penelitiannya penulis menggunakan metode penelitian hukum yuridis-normatif yang meliputi beberapa hal diantaranya adalah : ${ }^{6}$

1. Penelitian dengan menggunakan asas-asas hukum;

2. Penelitian dengan menggunakan sistematika hukum;

3. Penelitian dengan menggunakan taraf sinkronisasi hukum;

4. Penelitian yang mengacu pada sejarah hukum;

5. Penelitian dengan menggunakan perbandingan hukum.

Pada penelitian skripsi ini pada dasarnya lebih terarah dan terfokus pada penelitian dengan menggunakan asas-asas hukum. Penelitian tentang “Analisis Kekuatan Hukum Perjanjian Lisan Arisan Online Yang Menggunakan Media Aplikasi Facebook Messanger Dalam Pembuktian di Pengadilan (Studi Putusan Pengadilan Negeri Palangkaraya Nomor

6) ${ }^{6}$ ) Soerjono Soekanto, Pengantar Penelitian Hukum, Cet.3, (Jakarta: Penerbit Universitas Indonesia - UI Press, 2010), hal. 51. 
Lidya Puspita \& Ariawan Gunadi ANALISIS KEKUATAN HUKUM PERJANJIAN LISAN ARISAN ONLINE YANG MENGGUNAKAN MEDIA APLIKASI FACEBOOK MESSENGER DALAM PEMBUKTIAN DI PENGADILAN DITINJAU DARI UNDANG- UNDANG INFORMASI DAN TEKNOLOGI ELEKTRONIK NOMOR 11 TAHUN 2008 (STUDI KASUS PUTUSAN NO. 106/PDT.G/2017/PN.PLK)

Volume 2 Nomor 2, Desember 2019

E-ISSN : 2655-7347

106/PDT.G/2017/PN.PLK)”. Sebagai suatu penelitian yuridis normatif, maka penelitian ini mengacu pada norma hukum, baik ketentuan dalam perundang-undangan dan hukum sebagai putusan pengadilan. ${ }^{7}$ Berdasarkan hal tersebut objek yang dianalisis adalah berdasarkan norma hukum, yaitu ketentuan undang-undang dan ketetapan pengadilan.

Di dalam penelitian ini alat pengumpulan data yang dipergunakan adalah studi kepustakaan (library research). Teknik analisis data yang digunakan adalah teknik analisis normatif-kualitatif. Teknik analisis normatif-kualitatif ini mengkaji pertimbangan hukum hakim di dalam Putusan Pengadilan Negeri Palangkaraya Nomor 106/PDT.G/2017/PN.PLK mengenai perjanjian lisan arisan online yang menggunakan media aplikasi facebook messanger dalam pembuktian di pengadilan ditinjau dari UU ITE kemudian menuangkannya ke dalam bentuk kalimat atau narasi.

\section{PEMBAHASAN}

A. Kekuatan Hukum Perjanjian Lisan Arisan online yang Menggunakan Media Aplikasi Facebook Messenger dalam Pembuktian di Pengadilan Ditinjau dari UU ITE (Studi Kasus Putusan Nomor 106/Pdt.G/2017/PN.Plk

Berdasarkan pada acuan hukum di Indonesia, terkait dengan perjanjian tentunya harus bersumbe rdari suatu bentuk perjanjian atau perikatan seperti yang terkandung dalam Pasal 1313 KUHPerdata. Pasal 1338 KUHPerdata merupakan pasal yang paling dominan dalam asas kebebasan berkontrak, sedangkan pada Pasal 1320 yang mengandung 4 syarat diantaranya adalah adanya kata sepakat untuk suatu pengikatan diri, suatu kecakapan dalam membuat atau melakukan suatu perjanjian/ perikatan, adanya suatu hal tertentu yang mengikat dan adanya adanya suatu sebab yang halal.

\footnotetext{
7) 7 Ibid, hal 51 .
} 
Lidya Puspita \& Ariawan Gunadi ANALISIS KEKUATAN HUKUM PERJANJIAN LISAN ARISAN ONLINE YANG MENGGUNAKAN MEDIA APLIKASI FACEBOOK MESSENGER DALAM PEMBUKTIAN DI PENGADILAN DITINJAU DARI UNDANG- UNDANG INFORMASI DAN TEKNOLOGI ELEKTRONIK NOMOR 11 TAHUN 2008 (STUDI KASUS PUTUSAN NO. 106/PDT.G/2017/PN.PLK)

Volume 2 Nomor 2, Desember 2019

E-ISSN : 2655-7347

Dalam aspek lain, perjanjian dalam bentuk lisan dilakukan karena saling percaya, walaupun perjanjian secara lisan ini sudah diakomodir oleh aturan atau ketentuan hukum dalam KUHPerdata dan adanya asas pacta sun servanda namun dalam praktiknya, perjanjian lisan ini dapat dicurangi dengan berbagai cara mengingat tidak ada bukti tertulisnya.

Bukti tertulis atau bukti surat dalam suatu perjanjian keberadaannya adalah penting karena dalam proses pembuktian (apabila menjadi sengketa) alat bukti yang dipergunakan oleh pihak yang mendalilkan sesuatu (Pasal 163 HIR) adalah alat bukti surat. Hal ini karena dalam suatu hubungan keperdataan, suatu surat/akta memang sengaja dibuat dengan maksud untuk memudahkan proses pembuktian dan tak terkalah penting sebaiknya di dalam HIR ditambahkan mengenai perincian tentang perjanjian lisan dan tak terkalah penting adalah adanya saksiyang mampu membuktikan adanya suatu perjanjian dengan menunjukkan minimal adanya bukti saksi yaitu dua orang saksi atua satu saksi disertai bukti lain atau adanya suatu persekongkolan.

Perjanjian lisan bisa dibuktikan, selagi ada saksi-saksi yang menyaksikan perjanjian lisan tersebut dan semakin banyak saksi maka semakin bagus aspek pembuktiannya yaitu minimal ada dua orang saksi yang tujuannya menguatkan dalil mengenai adanya suatu perjanjian utang piutang secara lisan, mengenai minimum pembuktian, di mana saksi dalam hukum perdata dikenal prinsip unus testis nullus testis (Pasal 1905 KUHPerdata), sedangkan dalam perjanjian lisan harus ada aspek kepastian hukum bila terjadi sengketa di kemudian hari.

Perjanjian atau perikatan yang diatur dalam undang-undang pada dasarnya harus bisa diimplementasikan, sehingga menimbulkan akibat hukum manakala perjanjian itu dibuat menjadi tidak sah, sehingga batal demi hukum, dan tidak menimbulkan suatu perjanjian. ${ }^{8)}$ Di sisi lain, perjanjian lisan dalam hal ini juga tidak dapat diterapkan dalam perjanjian

8)8) Muhammad Syaifuddin, Hukum Kontrak: Memahami Kontrak dalam Perspektif Filsafat, Teori, Dogmatik dan Praktik Hukum, (Bandung: CV. Mandar Maju, 2012), hal. 147. 
Lidya Puspita \& Ariawan Gunadi

ANALISIS KEKUATAN HUKUM PERJANJIAN LISAN ARISAN ONLINE YANG MENGGUNAKAN MEDIA APLIKASI FACEBOOK MESSENGER DALAM PEMBUKTIAN DI PENGADILAN DITINJAU DARI UNDANG- UNDANG INFORMASI DAN TEKNOLOGI ELEKTRONIK NOMOR 11 TAHUN 2008 (STUDI KASUS PUTUSAN NO. 106/PDT.G/2017/PN.PLK)

Volume 2 Nomor 2, Desember 2019

E-ISSN : 2655-7347

atua perikatan yang telah ditetapkan atau mengacu pada undang-undang yang dibuat dalam bentuk tertulis, maka dalam hal ini perjanjian lisan tetaplah sah sebagai suatu perjanjian yang mengikat para pihak yang membuatnya dan sedangkan penyelesaian bila terjadi wanprestasi adalah Pasal pada Pasal 1338 ayat (1) KUH Perdata. Berdasarkan hal tersebut, jelas bahwa sah atau tidak sahnya suatu perjanjian tentu dapat dipastikan dengan mengujinya menggunakan instrumen atau alat hukum berdasarkan peraturan perundangan-undangan yang berlaku dan sifatnya mengikat. Dalam perjanjian lisan terkandung suatu makna janji yang dianggap sebagai elemen konstitutif dari suatu kekuatan perjanjian yang sifatnya mengikat. ${ }^{9)}$

Berdasarkan hubungan tersebut dan adanya kesepakatan secara lisan. Di mana perjanjian lisan artinya tetap sah, namun manakala ada sengketa atau masalah maka hal tersebut sulit dibuktikan (aspek pembuktiannya menjadi sulit). Mengacu pada Pasal 5 UU I T E yaitu :

1. Mengenai adanya informasi elektronik atau hasil cetaknya merupakan alat bukti hukum yang sah.

2. Mengenai informasi elektronik atau hasil cetaknya sebagaimana dimaksud pada ayat (1) merupakan perluasan dari alat bukti yang sah sesuai dengan Hukum Acara yang berlaku di Indonesia.

3. Mengenai informasi elektronik dan/atau dokumen elektronik yang dinyatakan sah apabila menggunakan sistem elektronik harus sesuai dengan aturan dan ketentuan UU.

4. Mengacu pada aturan/ketentuan terhadap informasi elektronik seperti pada ayat (1) tidak berlaku untuk peruntukan seperti :

a. Di mana surat menurut UU harus dibuat dalam bentuk tertulis; dan

b. Di mana surat beserta dokumennya menurut UU harus dibuat dalam bentuk akta notaril atau akta yang dibuat oleh pejabat pembuat akta.

999) Ibid., hlm. 137. 
Lidya Puspita \& Ariawan Gunadi

ANALISIS KEKUATAN HUKUM PERJANJIAN LISAN ARISAN ONLINE YANG MENGGUNAKAN MEDIA APLIKASI FACEBOOK MESSENGER DALAM PEMBUKTIAN DI PENGADILAN DITINJAU DARI UNDANG- UNDANG INFORMASI DAN TEKNOLOGI ELEKTRONIK NOMOR 11 TAHUN 2008 (STUDI KASUS PUTUSAN NO. 106/PDT.G/2017/PN.PLK)

Volume 2 Nomor 2, Desember 2019 E-ISSN : 2655-7347

Tentunya sebagai alat pelengkap, atas uraian tersebut dan berdasarkan keberadaan informasi elektronik dan/atau dokumen elektronik adalah mengikat dan akan memberikan kepastian hukum dalam aspek pembuktiannya secara elektronik.

Dalam hubungannya dengan Pasal 5 ayat (2) UU ITE mengatur bahwa Informasi Elektronik dan/atau Dokumen Elektronik dan/atau hasil cetaknya merupakan perluasan dari alat bukti hukum yang sah sesuai dengan hukum acara yang berlaku di Indonesia. Yang dimaksud dengan perluasan di sini maksudnya: menambah alat bukti yang telah diatur dalam hukum acara pidana di Indonesia, di mana informasi elektronik dan/atau dokumen elektronik sebagai alat bukti elektronik menambah jenis alat bukti yang diatur dalam KUHAP.

Berdasarkan aturan atau ketentuan dari Pasal 5 ayat (2) UU ITE, maka agar informasinya dapat dipercaya, entu harus ada otoritas data tertentu yang bertanggungjawab mengelola dokumen elektronik di suatu lembaga. Guna melengkapi atau menutupi kelemahan otoritas data yang belum semua dimiliki di berbagai lembaga, maka hasil cetakan dokumen elektronik masih diperlukan dalam proses pembuktian karena ada otentikasi dari pihal terkait sebagaimana kelaziman administrasi Negara termasuk pembuktian dalam perjanjian tertulis.

Terkait dengan perjanjian arisan secara online, bilamana timbul suatu permasalahan maka hal tersebut akan diselesaikan melalui gugatan inkar janji atau wanprestasi, di mana hal ini memang sulit aspek pembuktiannya terkait dengan arisan online. Namun untuk menentukan kapan harus menggunakan pasal-pasal ini untuk memperkuat hukum dalam suatu perjanjian terhadap para pihak juga kita harus memenuhi unsur-unsur sebelum mengambil langkah hukum. Apabila langkah tersebut tidak berhasil baru kemudian melakukan tindakan hukum.

Mengacu pada putusan Putusan No. 106/Pdt.G/2017/PN.PLK, di mana penggugat juga mengajukan bukti saksi. Dalam hal menyampaikan 
Lidya Puspita \& Ariawan Gunadi ANALISIS KEKUATAN HUKUM PERJANJIAN LISAN ARISAN ONLINE YANG MENGGUNAKAN MEDIA APLIKASI FACEBOOK MESSENGER DALAM PEMBUKTIAN DI PENGADILAN DITINJAU DARI UNDANG- UNDANG INFORMASI DAN TEKNOLOGI ELEKTRONIK NOMOR 11 TAHUN 2008 (STUDI KASUS PUTUSAN NO. 106/PDT.G/2017/PN.PLK)

Volume 2 Nomor 2, Desember 2019

E-ISSN : 2655-7347

kesaksian, menurut Hukum Acara Perdata saksi harus disumpah terlebih dahulu untuk dapat menguatkan dan membenarkan dalil-dalil yang telah penggugat ajukan. Bahwa dalam perkara ini, Penggugat mengajukan dua orang saksi dalam persidangan untuk didengarkan kesaksiannya yaitu: Dewi Rejeki dan Obryan Lorenzo Gampa.

Berdasarkan alat-alat bukti yang diajukan tersebut, Penggugat memperkuat kedudukannya agar gugatannya dapat dikabulkan, sebagai tindak lanjut pembuktian di persidangan, maka hakim melakukan musyawarah guna memutuskan perkara. Putusan yang dikeluarkan hakim terhadap perkara yakni menyatakan para tergugat secara sah dan menyakinkan telah melakukan ingkar janji (wanprestasi) yang berarti pihak tergugat harus melaksanakan tanggung jawabnya membayar ganti kerugian biaya perkara dan uang paksa atau dengan kata lain dwangsom seperti dijelaskan dalam dalil penggugat dalam gugatannya.

Secara rinci jumlah ganti kerugian yang harus dibayarkan para pihak adalah sebesar Rp 389.000.000,00 dan biaya perkara secara tanggung renteng sebesar Rp 4.738.000,00 dan uang paksa sebesar Rp 1.000.000,00. Akan tetapi biaya ganti kerugian yang tercantum dalam amar putusan tidaklah sama dengan yang tercantum dalam gugatan atau dapat dikatakan mengalami penurunan. Hal ini dikarenakan salah satu tergugat atas nama Dewi Rejeki telah mencapai kata damai dengan Penggugat. Dalam perkara ini membuktikan bahwa perdamaian menghapuskan kewajiban membayar ganti kerugian.

Majelis Hakim menyatakan pokok sengketa dalam kasus ini adalah ingkar janjinya Para Tergugat untuk membayar iuran (uang) dalam kegiatan arisan, sehingga Para Tergugat yang telah melakukan perbuatan wanprestasi (ingkar janji) karena tidak memenuhi janjinya untuk melaksanakan pembayaran iuran pada waktu yang ditentukan oleh Penggugat. Majelis Hakim menghukum Para Tergugat untuk membayar ganti rugi kepada Penggugat sebesar Rp. 389.000.000,- (Tiga Ratus 
Lidya Puspita \& Ariawan Gunadi ANALISIS KEKUATAN HUKUM PERJANJIAN LISAN ARISAN ONLINE YANG MENGGUNAKAN MEDIA APLIKASI FACEBOOK MESSENGER DALAM PEMBUKTIAN DI PENGADILAN DITINJAU DARI UNDANG- UNDANG INFORMASI DAN TEKNOLOGI ELEKTRONIK NOMOR 11 TAHUN 2008 (STUDI KASUS PUTUSAN NO. 106/PDT.G/2017/PN.PLK)

Volume 2 Nomor 2, Desember 2019

E-ISSN : 2655-7347

Delapan Puluh Sembilan Juta Rupiah). Dan berdasarkan putusan Majelis Hakim telah menjatuhkan putusan menerima dan mengabulkan apa yang menjadi perihal gugatan penggugat sebagian dan menolak gugatan penggugat selain dan selebihnya.

Berdasarkan ketentuan dari putusan Pengadilan Negeri Palangka Raya Nomor. 106/Pdt.G/2017/Pn Plk Pada Tanggal 18 Juli 2017 menjatuhkan perkara mengenai adanya kesepakatan kesepakatan bersama melakukan arisan online yang didaftarkan di Kepaniteraan Pengadilan Negeri Palangka Raya. Penulis sependapat pada pertimbangan hukum yang dilaksanakan oleh majelis hakim dikarenakan bahwa selama proses pemeriksaan ini berlangsung telah terjadi segala hal ihwal yang telah dicatat dalam berita acara persidangan. Berdasarkan maksud dan tujuan, di mana gugatan penggugat pada pokok perkaranya mengenai ingkar janji atau wanprestasi dikarenakan arisan online yang dilakukan oleh penggugat dengan para tergugat yaitu dilakukan dengan saling percaya satu sama lain tanpa adanya surat perjanjian yang benar adanya, dalam rumusan Pasal 1313 KUHPerdata.

Penulis sependapat bahwa pada proses mengadili majelis hakim menyatakan Penggugat telah mengalami kerugian moril dan rill. Dengan pertimbangan bahwa pada kerugian moril sejumlah Rp 10.000.000.000,tidak dapat dikabulkan karena tidak berdasarkan pada Pasal 1370, 1371, dan 1372 KUHPerdata (Putusan Peninjauan Kembali No.650/PK/Pdt/1994) dan menyatakan pada kerugian rill penggugat sejumlah Rp 389.000.000,- digantikan kerugiannya oleh para pihak tergugat berdasarkan ketentuan yang telah diberikan oleh majelis hakim pada musyawarah guna memutuskan perkara. Di mana jelas bahwa berdasarkan rumusan Pasal 1396 proses penyelesaian perkara perdata dilakukan seperti lazimnya proses pembuktian.

Berdasarkan hal ini pengugat mempunyai alat bukti seperti diatur dalam Pasal 164 HIR, Pasal 284 RBg dan pasal 1866 KUH Perdata adalah 
Lidya Puspita \& Ariawan Gunadi ANALISIS KEKUATAN HUKUM PERJANJIAN LISAN ARISAN ONLINE YANG MENGGUNAKAN MEDIA APLIKASI FACEBOOK MESSENGER DALAM PEMBUKTIAN DI PENGADILAN DITINJAU DARI UNDANG- UNDANG INFORMASI DAN TEKNOLOGI ELEKTRONIK NOMOR 11 TAHUN 2008 (STUDI KASUS PUTUSAN NO. 106/PDT.G/2017/PN.PLK)

Volume 2 Nomor 2, Desember 2019

E-ISSN : 2655-7347

berupa alat bukti surat (tulisan), alat bukti saksi, persangkaan (dugaan), pengakuan, dan sumpah. Pada perkara ini penggugat mendalilkan beberapa alat bukti tulisan yakni : Fotokopi bukti print out messege oleh para pihak tergugat, Fotokopi KTP Elektronik oleh AHHINY, Fotokopi Surat Perdamaian antara AHHINY (Penggugat) dengan salah satu member mines di Arisan Profit Bersama (Pro) bernama DEWI REJEKI, Fotokopi Surat Pernyataan dari Member Mines bersama DEWI REJEKI bersama dengan TITIS, dan surat somasi kepada para tergugat. Menurut Albert Arist di mana seseorang Penggugat dapat mengajukan saksi guna menguatkan dalil mengenai adanya suatu perjanjian hutang-piutang secara lisan, maka dalam hal ini dikenal prinsip Unus Testis Nullus Testis yang ditegaskan dalam Pasal 1907, di mana dalam hal ini Pengugat juga membukti alat bukti saksi yakni Dewi Rejeki dan Obryan Lorenzo dalam perkara ini untuk didengarkan kesaksiannya di muka persidangan. Berdasarkan alat-alat bukti yang diajukan tersebut, penggugat memperkuat kedudukannya agar gugatannya dapat dikabulkan sebagai tindak lanjut pembuktian di persidangan. Putusan yang di keluarkan majelis hakim terhadap perkara ini melalui musyawarah menyatakan para tergugat telah melakukan ingkar janji (wanprestasi) yang berarti pihak tergugat harus melaksanakan tanggung jawabnya.

Berdasarkan hal tersebut penulis sependapat dengan narasumber Advokat dari Law Office of Redol Panjaitan Sitepu \& Partners, Bapak David Manuel Sitepu, S.H., di mana dalam kasus ini alat buktinya berupa screenshot dari chatting di facebook messenger. Menurut UU ITE yaitu Pasal 5 ayat (1) dan (2) menyatakan bahwa Informasi Elektronik dan/atau Dokumen Elektronik dan/atau hasil cetaknya merupakan alat bukti yang sah, dan perluasan alat bukti yang sah menurut hukum acara yang berlaku di Indonesia pada dasarnya hasil cetak screenshot dari chatting di facebook messenger merupakan alat bukti surat yang membuktikan atau mendukung dalil Penggugat bahwa telah terjadinya persetujuan untuk 
Lidya Puspita \& Ariawan Gunadi

ANALISIS KEKUATAN HUKUM PERJANJIAN LISAN ARISAN ONLINE

YANG MENGGUNAKAN MEDIA APLIKASI FACEBOOK MESSENGER DALAM PEMBUKTIAN DI PENGADILAN DITINJAU DARI UNDANG- UNDANG INFORMASI DAN TEKNOLOGI ELEKTRONIK NOMOR 11 TAHUN 2008 (STUDI KASUS PUTUSAN NO. 106/PDT.G/2017/PN.PLK)

Volume 2 Nomor 2, Desember 2019

E-ISSN : 2655-7347

mengikatkan diri antar kedua belah pihak, dalam artian karena Penggugat yang mendalilkan maka harus Penggugat yang membuktikan (1865 KUH Perdata). Dan sesuai dengan dasar hukum bahwa hasil cetak screenshot dari chatting di facebook messenger dan bisa dijadikan alat bukti yang sah atau sebagai alat bukti surat. Hal ini jelas bahwa perjanjian lisan tersebut dalam hal ini harus didukung oleh alat bukti lain, dalam perkara tersebut dikuatkan dengan alat bukti surat dan saksi.

Penulis berpendapat bahwa Hukum Perdata tidak ada sama sekali menyarankan perjanjian dibuat dengan tertulis tetapi apabila terjadi wanprestasi sangat sulit untuk membuktikannya, sehingga diperlukan pengakun dari pihak lawan yang membuat perjanjian tersebut dan didengar oleh saksi-saksi di Persidangan, maka perjanjian tersebut telah terbukti adanya wanprestasi, sehingga apa yang telah dilakukan di dalam perjanjian tersebut terbukti adanya wanprestasi maka pihak yang harus menganti kerugian yang timbul dari perjanjian tersebut.

Berdasarkan hal tersebut perjanjian lisan tetaplah sah dan memiliki kekuatan hukum untuk menyatakan seseorang melakukan ingkar janji atau wanprestasi, namun bilamana perjanjian lisan tersebut tidak diakui atau dibantah oleh pihak yang diduga melakukan ingkar janji atau wanprestasi, maka perjanjian lisan tersebut tentu tidak mempunyai kekuatan hukum dan menyatakan bahwa seseorang tersebut yang melakukan wanprestasi, karena dalam perjanjian tersebut bisa benar dan fakta adanya dan bisa juga tidak ada, hal ini tergantung pada aspek pembuktian dari para pihak. Mengingat hal ini disebabkan karena ada atau tidaknya perjanjian sangat menentukan dalam menyatakan seseorang melakukan ingkar janji atau wanprestasi, karena seseorang tidak dapat dinyatakan wanprestasi apabila tidak ada perjanjian yang dibuatnya diantaran mereka (banyak pihak) dan dalam perjanjian lisan yang disangkal, dibantah atau dengan kata lain tidak diakui oleh salah satu pihak yang membuatnya, maka hal tersebut tentunya tidak memiliki kekuatan hukum guna menyatakan seseorang melakukan 
Lidya Puspita \& Ariawan Gunadi ANALISIS KEKUATAN HUKUM PERJANJIAN LISAN ARISAN ONLINE YANG MENGGUNAKAN MEDIA APLIKASI FACEBOOK MESSENGER DALAM PEMBUKTIAN DI PENGADILAN DITINJAU DARI UNDANG- UNDANG INFORMASI DAN TEKNOLOGI ELEKTRONIK NOMOR 11 TAHUN 2008 (STUDI KASUS PUTUSAN NO. 106/PDT.G/2017/PN.PLK)

Volume 2 Nomor 2, Desember 2019

E-ISSN : 2655-7347

wanprestasi, namun perjanjian lisan yang telah disangkal/tidak diakui dapat mendapatkan kembali kekuatan hukumnya jika dapat dibuktikan bahwa perjanjian lisan tersebut benar-benar ada atau pernah dibuat. Intinya bahwa dalam suatu perjanjian lisan pada dasarnya harus memiliki kekuatan hukum yang mengikat antar berbagai pihak yang terlibat di dalamnya, hal ini selaras dengan aturan dan ketentuan Pasal 1320 KUH Perdata.

B. Tanggung Jawab Facebook dalam Hal Perjanjian Lisan Arisan Online yang Menggunakan Media Aplikasi Facebook Messenger apabila Terjadi Wanprestasi

Mengenai tanggungjawab hukum dalam KUHPerdata yang berupa tanggung jawab seseorang terhadap perbuatan melawan hukum. Di mana perbuatan melawan hukum tersebut memiliki cakupan yang luas dibandingkan dengan perbuatan pidana. Perbuatan melawan hukum tentunya tidak hanya mencakup perbuatan yang bertentangan dengan undang-undang pidana saja melainkan pada perbuatan yang bertentangan dengan undang-undang lainnya dan bahkan dengan ketentuan-ketentuan hukum yang tidak tertulis. Ketentuan perundang-undangan dari perbuatan melawan hukum tersebut bertujuan untuk melindungi dan memberikan ganti rugi kepada pihak yang dirugikan dalam perjanjian tersebut. ${ }^{10)}$

Perjanjian arisan secara online pada dasarnya akan menimbulkan hak dan kewajiban sesuai dengan penyelesaian di atas, dalam beberapa perkara mengenai arisan online ini tergugat sebagai owner atau pengurus arisan yang telah melakukan wanprestasi manakala tidak memenuhi kewajibannya atau wanprestasi yaitu membayarkan uang yang menjadi hak peserta arisan sesuai dengan aturan yang telah disepakati dalam perjanjian tersebut. Namun, tidak semua perkara mengenai arisan online seorang owner/pengurus arisan akan bersalah. Tugas dan tanggung jawab

10)10) Komariah, Edisi Revisi Hukum Perdata, (Malang: Universitas Muhammadiyah Malang, 2001), hal. 12 
Lidya Puspita \& Ariawan Gunadi

ANALISIS KEKUATAN HUKUM PERJANJIAN LISAN ARISAN ONLINE YANG MENGGUNAKAN MEDIA APLIKASI FACEBOOK MESSENGER DALAM PEMBUKTIAN DI PENGADILAN DITINJAU DARI UNDANG- UNDANG INFORMASI DAN TEKNOLOGI ELEKTRONIK NOMOR 11 TAHUN 2008 (STUDI KASUS PUTUSAN NO. 106/PDT.G/2017/PN.PLK)

Volume 2 Nomor 2, Desember 2019

E-ISSN : 2655-7347

dari seorang bandar atau pengurus arisan pada setiap kasus memang tidak dapat disamaratakan dan tentunya berbeda.

Pelaksanaan perjanjian lisan arisan online menggunakan media facebook dilakukan secara online dan tidak tatap muka, tetapi melalui akun media sosial facebook dengan sistem pengocokan yang dilakukan sebulan sekali. Admin arisan dalam hal ini akan membuat kesepakatan nominal yang akan dibayar oleh anggota arisan, dan guna permulaan nomor urut pertama yang berhak mendapatkan arisan adalah admin arisan sendiri dan selanjutnya akan memakai sistem kocok sampai dengan seterusnya dan langsung melangsungkan akad untuk arisan melalu media sosial juga tentunya. Berdasarkan hal tersebut di atas dapat diinterpretasikan bahwa semua anggota benar-benar telah menyetujui isi perjanjian arisan secara online dan sistem arisan yang mereka lakukan, meskipun dengan tidak bertemu dan telah menyepakati nilai nominal uang pertama setiap bulannya, sehingga kecil terjadinya permasalahan hukum dalam artinya perselisihan antara admin arisan dan anggota arisan lainnya.

Adanya perjanjian secara lisan melalui facebook pada dasarnya akan menimbulkan suatu hubungan hukum yang melibatkan setidaknya dua pihak, yaitu pihak yang melakukan arisan secara online dan websiteonline, yang dalam hal ini adalah facebook. Namun, dari kedua pihak tersebut pihak-pihak yang terlibat secara langsung adalah pihak yang melakukan arisan secara online yang dalam hal ini facebook. Dan facebook sendiri tidak terlibat secara langsung dalam transaksi perjanjian lisan arisan online dilakukan oleh kedua belah dan facebook hanya merupakan sebagai sarana atau media dalam pelaksanaan perjanjian arisan secara online.

Facebook adalah salah satu situs jejaring sosial yang ada di jagad web atau dunia maya, sehingga dalam hal ini pengguna facebook tentu dapat memahami bahwa batasan tanggung jawab facebook secara proporsional adalah sebagai penyedia jasa portal website. 
Lidya Puspita \& Ariawan Gunadi ANALISIS KEKUATAN HUKUM PERJANJIAN LISAN ARISAN ONLINE YANG MENGGUNAKAN MEDIA APLIKASI FACEBOOK MESSENGER DALAM PEMBUKTIAN DI PENGADILAN DITINJAU DARI UNDANG- UNDANG INFORMASI DAN TEKNOLOGI ELEKTRONIK NOMOR 11 TAHUN 2008 (STUDI KASUS PUTUSAN NO. 106/PDT.G/2017/PN.PLK)

Volume 2 Nomor 2, Desember 2019

E-ISSN : 2655-7347

Hubungan hukum dalam perjanjian arisan secara online dilakukan para pihak tentunya harus mengikuti ketentuan hukum yang berlaku yang dalam hal ini ialah syarat sahnya perjanjian sebagaimana yang dimaksud Pasal 1320 Kitab Undang-Undang Hukum Perdata. Berdasarkan hal tersebut maka pengaturan tersebut para pihak wajib untuk dan tetap harus mengikuti atau mematuhi perjanjian yang berlaku tersebut. Apabila ada salah satu pihak yang mengingkari perjanjian tersebut maka terjadi wanprestasi atau ingkar janji diantara para pihak. Apabila terjadi wanprestasi dalam hubungan hukum penggunaan facebook sebagai sarana dalam arisan secara online, para pihak yang merasakan dirugikan tentunya dapat menempuh upaya atau jalur litigasi atau non litigasi. Dalam hal ini, facebook hanya sebagai perantara dan facebook tidak bertanggung jawab atas perselisihan atau wanprestasi yang terjadi diantara para pihak arisan online yang menggunakan media facebook.

\section{P E N U T U P}

\section{A. Kesimpulan}

Berdasarkan pembahasan yang dijelaskan di atas, maka Penulis sampailah pada kesimpulan akhir, yakni :

1. Kekuatan hukum perjanjian lisan arisan online yang menggunakan media aplikasi facebook messenger dalam pembuktian di pengadilan ditinjau berdasarkan UU ITE dalam Putusan No. 106/Pdt.G/2017/PN.PLK, di mana hasil cetak screenshot dari chatting di facebook messenger merupakan bukti atau alat bukti yang sah atau sebagai alat bukti surat. Perjanjian lisan arisan online dalam kasus ini bersifat perjanjian lisan dengan saling percaya antara satu dengan yang lain dan akan menimbulkan hak dan kewajiban di antara para pesertanya. Perjanjian ini akan mempunyai kekuatan hukum apabila para pihak arisan tersebut telah sepakat dan mengikatkan diri guna mengadakan suatu arisan dengan besaran nilai uang atau barang tertentu untuk periode waktu tertentu, ini 
Lidya Puspita \& Ariawan Gunadi

ANALISIS KEKUATAN HUKUM PERJANJIAN LISAN ARISAN ONLINE YANG MENGGUNAKAN MEDIA APLIKASI FACEBOOK MESSENGER DALAM PEMBUKTIAN DI PENGADILAN DITINJAU DARI UNDANG- UNDANG INFORMASI DAN TEKNOLOGI ELEKTRONIK NOMOR 11 TAHUN 2008 (STUDI KASUS PUTUSAN NO. 106/PDT.G/2017/PN.PLK)

Volume 2 Nomor 2, Desember 2019

E-ISSN : 2655-7347

tentu sudah dikatakan bahwa para peserta arisan tersebut pada dasarnya telah terjadi suatu perjanjian.

2. Hubungan hukum dalam perjanjian arisan secara online dilakukan para pihak tentunya harus mengacu pada aturan hukum atau ketentuan yang telah disepakati banyak pihak dalam perjanjian, syarat sahnya perjanjian sebagaimana yang dimaksud Pasal 1320 KUHPerdata telah diatur mengenai hak dan kewajiban para pihak. Dengan pengaturan tersebut peserta arisan wajib untuk mengikuti atau mematuhi perjanjian yang berlaku tersebut. Apabila ada salah satu pihak yang mengingkari perjanjian tersebut maka terjadi wanprestasi atau ingkar janji diantara para pihak. Apabila terjadi wanprestasi dalam hubungan hukum penggunaan facebook sebagai sarana dalam arisan secara online, para pihak yang merasakan dirugikan tentunya dapat menempuh upaya atau jalur litigasi atau non litigasi. Dalam hal ini, facebook hanya sebagai perantara dan facebook tidak bertanggung jawab atas perselisihan atau wanprestasi yang terjadi diantara para pihak arisan online yang menggunakan media facebook.

\section{B. Saran}

Mengacu pada apa yang diuraikan di atas, saran yang bisa Penulis sampaikan adalah:

1. Terkait dengan aspek pembuktian dalam perjanjian lisan ada bukti email, bukti hasil cetak screenshot dari chatting di facebook messenger merupakan alat bukti yang sah sebagai alat bukti surat dan kalau diprint tentunya memiliki kekuatan hukum dan bisa menjadi alat bukti tertulis dan dalam hal ini tidak semua penyidik maupun hakim menerapkan hal tersebut sebagai alat bukti. Di sisi lain, perjanjian secara lisan tentunya harus dilakukan oleh para pihak yang membuat perjanjian/perikatan, mengingat para pihak yang dimaksud tentunya harus mentaati atau mengikatu aturan yang tertera dalam perjanjian, dan kewajiban itu lahir 
Lidya Puspita \& Ariawan Gunadi ANALISIS KEKUATAN HUKUM PERJANJIAN LISAN ARISAN ONLINE YANG MENGGUNAKAN MEDIA APLIKASI FACEBOOK MESSENGER DALAM PEMBUKTIAN DI PENGADILAN DITINJAU DARI UNDANG- UNDANG INFORMASI DAN TEKNOLOGI ELEKTRONIK NOMOR 11 TAHUN 2008 (STUDI KASUS PUTUSAN NO. 106/PDT.G/2017/PN.PLK)

Volume 2 Nomor 2, Desember 2019

E-ISSN : 2655-7347

dari perjanjian itu sendiri yang berkekuatan sebagai UU bagi para pihak yang membuatnya (rumusan Pasal 1338 KUHPerdata), sepanjang perjanjian itu dinyatakan sah sesuai dengan ketentuan Pasal 1320 KUHPerdata yang menjadi syarat sahnya perjanjian.

2. Seiring dengan kemajuan teknologi dan perkembangan teknik informasi yang semakin cepat saat ini, diharapkan peran Pemerintah untuk segera mengakui bahwa bukti elektronik bisa diakui dan dijadikan sebagai alat bukti di persidangan. Jaksa sebagai pihak yang punya kewajiban membuktikan dakwaan di pengadilan maka bukti elektronik dijadikan sebagai petunjuk untuk menunjang bukti lainnya. Dan dalam hubungannya dengan media yang digunakan dalam perjanjian lisan arisan online yang menggunakan sarana media facebook, facebook dalam hal ini hanya sebagai perantara dan facebook tidak bertanggung jawab atas perselisihan atau wanprestasi yang terjadi diantara para pihak arisan online yang menggunakan media facebook.

3. Saran bagi pembangunan hukum di Indonesia terkait perjanjian lisan arisan online, di mana aspek penegakan hukum pidana terhadap pelaku dalam perjanjian arisan online ini dilakukan berdasrkan ketentuan/aturan KUHP dan karena didalam kasus perjanjian arisan online tersebut terdapat unsur penipuan dikenakan Pasal 378 KUHP, maka dalam hal ini aspek penegakan hukumnya dimulai dari beberapa tahapan, tetapi karena dalam Pasal 378 KUHP tentunya dalam hal ini mengakibatkan ancaman pidananya terlalu ringan, maka dalam hal ini penegak hukum yaitu pihak kepolisian bisa menggunakan ketentuan Pasal 28 ayat (1) dan Pasal 45 ayat (2) UU ITE yang sudah mampu menjerat pelaku.

\section{DAFTAR PUSTAKA}

\section{A. Buku}

Fuady, Munir. Hukum Kontrak (Dari Sudut Pandang Hukum Bisnis). Buku Kedua, (Bandung: PT. Citra Aditya Bakti, 2001). 
Lidya Puspita \& Ariawan Gunadi ANALISIS KEKUATAN HUKUM PERJANJIAN LISAN ARISAN ONLINE YANG MENGGUNAKAN MEDIA APLIKASI FACEBOOK MESSENGER DALAM PEMBUKTIAN DI PENGADILAN DITINJAU DARI UNDANG- UNDANG INFORMASI DAN TEKNOLOGI ELEKTRONIK NOMOR 11 TAHUN 2008 (STUDI KASUS PUTUSAN NO. 106/PDT.G/2017/PN.PLK)

Volume 2 Nomor 2, Desember 2019

E-ISSN : 2655-7347

Komariah. Edisi Revisi Hukum Perdata. (Malang: Universitas Muhammadiyah Malang, 2001).

Rahardjo, Agus. Cyber Crime atas Pemahaman dan Upaya Pencegahan Kejahatan Berteknologi. (Bandung: Citra Aditya Bakti, 2002).

Saifuddin, Muhammad. Hukum Kontrak: Memahami Kontrak dalam Perspektif Filsafat, Teori, Dogmatik dan Praktik Hukum. (Bandung: CV. Mandar Maju, 2012).

Soekanto, Soerjono. Pengantar Penelitian Hukum. Cet.3. (Jakarta: Penerbit Universitas Indonesia - UI Press, 2010).

Subekti, R. Hukum Perjanjian. (Jakarta: Intermassa, 1996).

\section{B. Peraturan Perundang-Undangan}

Undang-Undang Nomor 37 Tahun 2004 tentang Kepailitan dan Penundaan Kewajiban Pembayaran Utang.

\section{Kamus}

Poerwadarminta, W.J.S. Kamus Umum Bahasa Indonesia. (Jakarta: Balai Pustaka, 2007). 